\title{
Vejledning på norsk - fra hovedværker til foldere
}

\author{
Anmeldelse af Lotte Rienecker
}

Handal, Gunnar; Lauvås, Per (2006): Forskningsveilederen. Oslo, J.W. Cappelens Forlag AS, $265 \mathrm{~s}$.

Dysthe, Olga; Samara, Akylina (2006): Forskningsveiledning på masterog doktorgradsniveau. Trondheim, Abstrakt Forlag, $353 \mathrm{~s}$.

Folkvord, Ingvild (2005): Patentlosninger og Fingerspitzengefühl - om a veilede til PhD-graden. Trondheim, Tapir Akademisk Forlag, $90 \mathrm{~s}$

Lie, Sissel (2006): Kjøreregler for PhD-vejledning:

http://www.hf.ntnu.no/hf/adm/forskerutdanning/phd/Veiledning/Veiledningsbrosjyren.pdf, 4 s.folder.

Fire norske udgivelser fra de seneste par år strækker sig genremæssigt fra nærmest monumentale universitetspædagogiske værker til en folder der indeholder essensen. Indhold og synsvinkler er meget genkendelige både teksterne imellem (alle forfattere er dybt integreret i norske universitetspædagogiske kredse) og for os danskere.

Handal og Lauvås har skrevet et hovedværk i vejledningslitteraturen. Bogen er informeret af den internationale vejledningslitteratur, af forfatternes egen empiriske vejledningsstudie fra 1997, og i høj grad af deres egne erfaringer med speciale- og forskningsvejledning. Temaer er bl.a. vejlednings variation over fagkulturer, vejledningsrelationen, feedback, de studerendes investering $i$ vejledningen, vejledning med studerende i krise, af kvindelige studerende, udenlandske studerende, gruppe- og netvejledning. Bogen har en dybt sympatisk, empatisk og pædagogisk tone med fokus på vejlederens personlige muligheder i relationen til sine studerende. Skal man absolut kritisere den for noget, er det at tekstens plads i vejledningen: Vejledningens genstand ikke fylder så meget, og derfor bliver det også utydeligt hvad der egentlig er forskelle på at vejlede speciale- og ph.d.-studerende. En væsentlig forskel er bl.a. at ph.d.-skriveren har lavet projektoplæg, og vejledningen tager således allerede udgangspunkt $i$ dette, man skal ikke forst fra emne til problemformulering og tekstens centrale styrepinde, en proces som kan fylde meget i specialevejledning. Handal og Lauvås er professorer i faget pædagogik, og selv om de skriver at vejlednings grundlæggende vilkår er at vejleder altid har for travlt, så får man alligevel som læser en fornemmelse af deres store tidsforbrug. En formaning til vejledere af udenlandske studerende om at sætte sig ind i kandidatens land og baggrund er et eksempel på dette som har fæstnet sig hos mig. Og hele pointen er selvfølgelig at der ingen vej er uden om at man må investere $\mathrm{i}$ god vejledning. Det gælder både tid og et fagligt og personligt engagement. Lauvås \& Handal minder os om at vejledning involverer hele mennesket, ikke isolerbart til faglige færdigheder på to ben.

Olga Dysthe (professor i Pædagogik) og Akylina Samara (førsteamanuensis, begge Universitetet i Bergen) har samlet antologien Forskningsveiledning på master- og doktorgradsniveau. Også de er grundpiller i det norske, universitetspædagogiske miljø. De 21 bidrag er skrevet af universitetspædagoger og af dels vejledere med særligt interessante vejledningstiltag (gruppe- og netvejledning) og en række erfarne repræsentanter for en lang række fagmiljøer (fra »hårde« til »bløde»). Genremæssigt er nogle artikler lærebogs-stof, andre er essays om egne vejleder-erfaringer. Blandt ekspertbidragene rager redaktørernes egne op: Olga Dysthes artikel »Rettleieren som lærar, partnar eller meister? « er allerede kendt, og den heri introducerede partnerskabs-model for vejledning citeres af mange (fx Lauvås \& Handal i dette nummer). Den defineres bl.a. sådan: »... dette inneber eit meir symmetrisk forhold [...] Når rettleiingsforholdet bliver oppfattet som partnerskap, bliver dialog den sentrale rettleiingsstrategien...« (2006, s. 236). Akylina Samara skriver i "Vanlige problemer i veilederforholdet illustrert gjennom case« meget genkendeligt og klart om styring og kritik af tekst som svært håndterbare, men helt almindelige udfordringer i ph.d.-vejledning. De mange bidrag fra gode, erfarne vejledere gør antologien til én af de mest ambitiøse skandinaviske publikationer af god-praksis-beretninger om universitetspædagogik, ganske som Kvalitet $i$ undervisningen (VTU, 2006) har anbefalet som et middel til universitetspædagogisk opkvalificering gennem erfaringsudveksling blandt peers. Bl.a. derfor er det interessant, men som læser finder jeg visse frustrationer ved de mange god-praksis-beretninger (mange gentagelser, svært at (gen)finde de praktisk anvendelige pædagogiske forslag i tekster hvor de ikke er fremhævede, men drukner lidt i refleksioner og ræsonnementer), men især at det netop kun er de gode praksisser $\mathrm{i}$ forhold til håndterbare udfordringer vi kommer til at høre noget om. Inviterer man til godpraksis-beretninger, så får man (idealiserede?) billeder af 
de situationer der går godt, og dem som bidragyderne vælger ud. Det er i det hele taget begrænsningen ved god-praksis-beretninger som bærende for pædagogik. De rigtigt svære (eller politisk/institutionelt ukorrekte) udfordringer: Hvordan man håndterer drop-out eller større brist på forudsætninger, mislykket forskning, manglende integration i diskursfællesskabet, eklatante vejledersvigt osv. dækkes ikke (her i en bog på 353 s.). Det må vi have til gode. Fordelen ved de mange stemmer er at de forskellige fagmiljøer hver kan finde sig selv, og samtidig kan alle nyde godt af de dele der er generelle. De færreste vil nok læse hele bogen.

Patentlosninger og Fingerspitzengefühl-Om à veilede til PhD-graden $(2005,90 \mathrm{~s}$.) af Ingvild Folkvord som er post-doc i Trondheim, er en lærebog i ph.d.-vejledning, (meget vel-)skrevet ud fra den vejledtes synspunkt. Hvad er det ph.d.erne typisk har brug for fra vejleder? Fra bogens huskelister: „Vurdere hvilke fagmiljøer og enkeltpersoner som vil kunne være av særlig interesse for stipendiaten. Bidra til at etablere med disse. [...] Veilede målrettet og problemorientert i forhold til forskningslitteraturen på feltet.[...] (s. 49) Bidra til at stipendiaten kommer i gang med skrivingen så raskt som mulig. [...] Bidra til å tydeliggjøre kravene til hva en $\mathrm{PhD}$-afhandling skal være og hvilke sjangernormer som gælder i fagfællesskabet«. (s. 75) Temaerne er de samme som i (alle?) bøger om vejledning: proces, tekst, inddragelse i fagmiljøer, vejledningsrelationen. Der er masser af gode råd i samlede huskelister, og Folkvord er ikke bange for at være normativ, at skrive hvad man kan og bør gøre. Patentløsninger... er en brugervenlig guide der forholder sig praktisk og engageret ud fra den vejledtes almindelige behov.

Lie, Sissel (2006): Kjøreregler for PhD-vejledning, en indbydende folder på 4 sider glittet papir og fint layout (kan downloades). Sissel Lie er professor i fransk og forskerskoleleder i Bergen og har med den kasket og autoritet skrevet en folder til vejledere, struktureret i temaerne Stipendiat og vejleder, Forskningsmiljø, Skriveprosess og Avhandlingen, og bygget op i sektioner omkring Vurder: og Husk: Eksempel fra Stipendiat og vejleder, Vurdér: "Har stipendiaten den kompetansen som er nødvendig eller trengs det kurs ut over skoleringsprogrammet? « Osv. Fire sider og masser af råd og tjeklister - så kort kan det gøres hvis afsender har positionen til at give retningslinjer og skrive i bydemåde. Den er god! Jeg er medforfatter til en vejledningsbog på 340 s., og lige nu synes jeg at den genre materiale om vejledning, vejledere og studerende især trænger til, er flere foldere. De vil blive læst!

Fire publikationer fra det store samlende hovedværk til næsten samme pointer kogt ned til en folder. Alle er de et must for alle der vil lære mere om vejledning. Alle disse publikationer bør ethvert institutbibliotek anskaffe og flest mulige vejledere bruge som ressourcer og til opslag. 